\title{
Productivity of the main ear of winter soft wheat varieties in ontogenesis
}

\author{
V. V. Kazakova*, V. S. Kazakova, N. V. Repko, and V. S. Dinkova \\ Kuban State Agrarian University, 350044, Krasnodar, Russia
}

\begin{abstract}
The study of the realization of the productivity potential of the main ear in winter wheat plants shows that the Pamyat variety most fully realizes the inherent genetic potential, forms a well-executed ear, but it is inferior to the experimental varieties in yield, which is explained by a lower level of productive bushiness of this variety. Varieties Kurs, Adel and Kalym, inferior to the ear of the ear, formed high yield indicators, due to a more powerful density of standing ears.
\end{abstract}

Wheat is one of the oldest and most famous agricultural crops. It is not known exactly where wheat originated, but many scientists suggest that the current form of wheat originated from three types of wild cereals that grew in areas of Asia Minor, Southern Europe and North Africa. This is the most valuable and common grain crop grown around the world.

The great popularity of wheat is due to the universal use of grain, which has a great nutritional value. Wheat can be used to produce: flour, pasta, confectionery, alcoholic beverages. Grain contains starch, protein, fat, sugars, fiber, ash elements and other substances, while starch - from 40 to $70 \%$, which is more than in any other crop, and the nutritional value of wheat is slightly inferior only to corn.

In Russia, wheat is one of the main strategic crops. In 2018, 72.1 million tons were collected in our country. Future increasing in the gross harvest of this crop can be ensured by the introduction of new high productive varieties and improvement of cultivation technologies.

Variety substitution is the least expensive form of crop yield stabilization, while the potential productivity of the ear of new introduced varieties plays an important role. This direction of research is reflected in the works of F. M. Kuperman, N. T. Nilovskaya, Z. A. Morozov, L. V. Tsatsenko, S. A. Koshkin, and V. V. Ivashchenko. Their works reflect the mechanisms of ontogenesis of winter soft wheat, questions and problems of realizing the reproductive potential, as well as the influence of external factors on the physiological processes of the plant $[1,2,5,6]$.

As a rule, the high potential productivity of modern varieties is not fully realized, the level of implementation depends on the creation of optimal conditions for the appropriate stages of organogenesis [3, 4].

The potential of varieties is largely determined by the content of nutrients, moisture, climate zone and many other factors in the soil. The realization of the inherent productivity

* Corresponding author: Kazakova.V@kubsau.ru 
occurs between the VI and IX stages of organogenesis (the beginning of the exit into the tube - the end of flowering). This period is called critical in the development of the plant and is characterized by high requirements of the plant to environmental factors. However, even in an environment close to optimal, the inherent productivity is not fully realized, which indicates a large genetic potential. [5, 6].

The purpose of our research was to study the potential productivity of the ear of winter wheat varieties selected by the National Research Center named after P. P. Lukyanenko.

The experiments were carried out at the experimental station of the Kuban State Agrarian University. The varieties Pamyat, Adel, Course, and Kalym were selected as the object of research. Field experiments were conducted according to the methodology of the State Commission for Variety Testing of Agricultural Crops (2019). The predecessor is winter rapeseed. In the process of processing the research results, the indicators of evidence-based statistics were calculated (B. A. Dospekhov 1985): the average value of the trait, the smallest significant difference (NSR). Data processing was carried out using the methods of variance, step-by-step multiple regression analysis, and experiment planning.

The study of potential productivity began at the VI stage of organogenesis, with a study of the number of laid flowers in the ear of wheat. The analysis of experimental data revealed that the largest number of laid flowers at the VI stage of organogenesis was in the variety Pamyat and amounted to 130 pieces, which was the best result in the experiment (Table 1).

Table 1. The indicators of realization of potential productivity of winter soft wheat varieties (KubSAU experimental station, 2017-2018)

\begin{tabular}{|l|c|c|c|}
\hline \multirow{2}{*}{ Variety } & \multicolumn{2}{|c|}{ Stages of organogenesis } & \multirow{2}{*}{$\begin{array}{c}\text { Realization of potential } \\
\text { productivity, \% }\end{array}$} \\
\cline { 2 - 3 } & VI & XII & \\
\cline { 2 - 3 } & flowers, pcs & grains, pcs & 45,4 \\
\hline Pamyat, st & 130 & 59 & 41,4 \\
\hline Course & 111 & 46 & 44,6 \\
\hline Kalym & 74 & 33 & 45,8 \\
\hline Adele & 96 & 44 & \\
\hline
\end{tabular}

In the Course variety, there were up to 111 flowers in the ear, which is less than in the Pamyat variety by 19 flowers. The Adele variety had 96 flowers, which is 15 flowers less than the Course variety and 34 flowers less than the Pamyat variety. For the Kalym variety, the smallest number of flowers was noted - 74 in the spike, which is 56 less than in the standard variety.

Similar data were available for the number of developed grains. The leading positions were held by the standard Pamyat. The experimental forms conceded to the standard, the Kalym variety formed 33 grains, which is less than the Pamyat variety by 26 grains, the Course and Adele varieties had similar data, 46 and 44 grains per spike.

The calculation of the productivity potential revealed that all the studied varieties realize it by more than $40 \%$. Higher rates are found at Adele, whose implementation was at 45,8 $\%$, and the best data in terms of experience, as well as varieties of Pamyat, which is almost half could realize the productive potential $(45,4 \%)$.

Based on the observations and measurements, we have compiled a graphical diagram showing the number of flowers laid and developed on the ears of the studied varieties (Figure 1).

Black squares mark the most developed flowers, which formed a well-executed, normally developed grain. Gray squares are laid flowers, in which by the XII stage of organogenesis, the grains were formed poorly developed. Empty white squares indicate the flowers that were laid at the VI stage of organogenesis and did not give grains, i.e. reduced. 
The analysis of this diagram shows that the average number of laid flowers on each ledge of the spike rod for all varieties was from 5 to 8 pieces. At the same time, most of the well-developed grains of all varieties are located in the lower middle part of the spike and make up from 2 to 4 grains.

The best results were shown by two varieties Pamyat and Course, they have the largest number of flowers with developed grains. In the varieties Kalym and Adele, the flowers with developed grains are evenly arranged along the length of the spike. However, these varieties have a large number of small poorly executed grains.

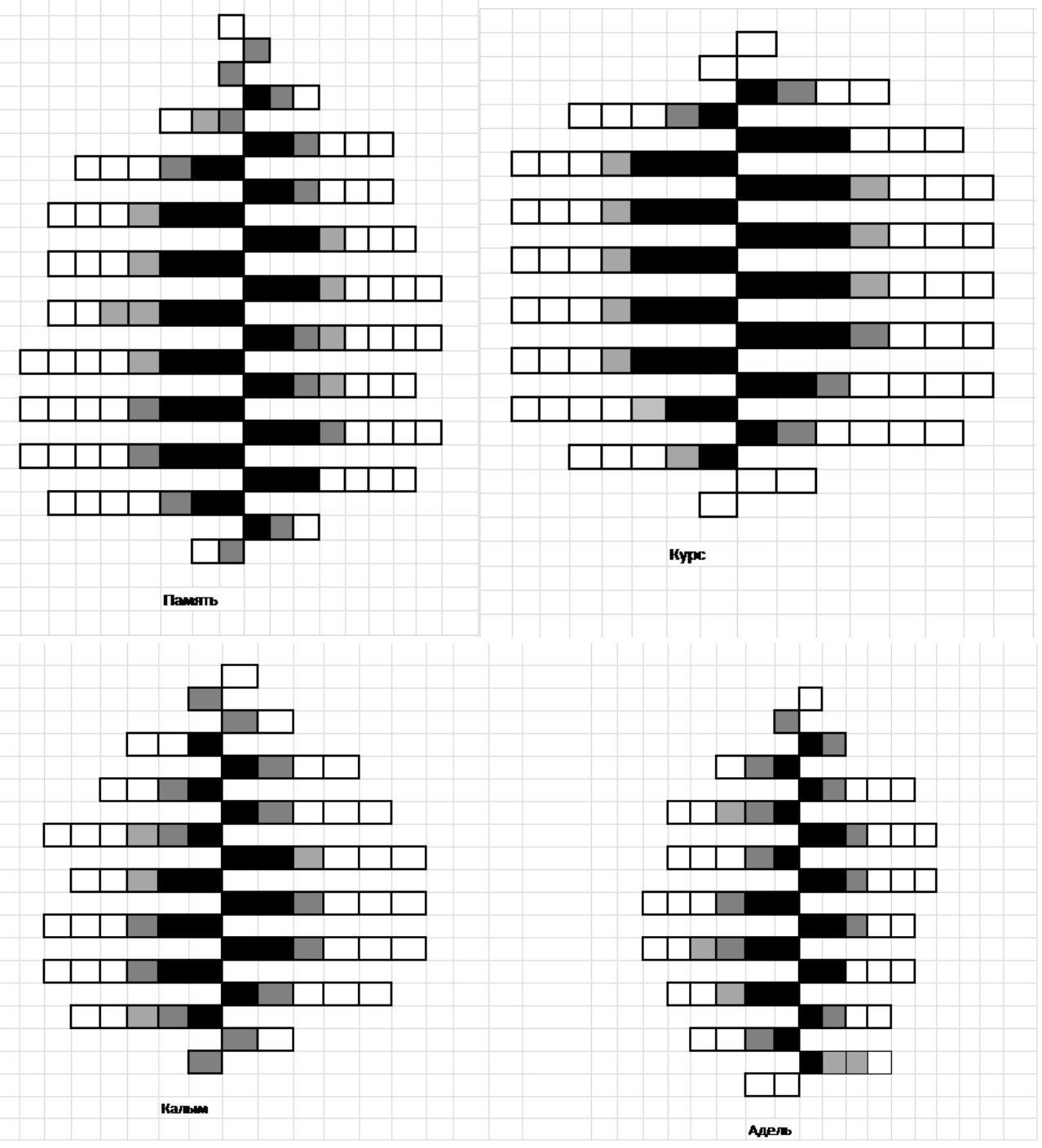

Fig. 1. Graphic diagram of the main ear of winter soft wheat varieties

The main indicators of the productivity of the wheat ear are: its length, the total number of spikelets, the number of underdeveloped spikelets, the number of grains, the weight of grain. The experimental data are shown in Table 2. 
Table 2. Productivity indicators of winter soft wheat varieties (KubSAU experimental station, 2017-2018)

\begin{tabular}{|l|c|c|c|c|c|c|c|}
\hline Variety & \multirow{2}{*}{$\begin{array}{c}\text { Ear } \\
\text { length, } \\
\text { cm }\end{array}$} & spikelets & $\begin{array}{c}\text { Number of, pcs. } \\
\text { underdeveloped } \\
\text { spikelets }\end{array}$ & grains & spike & grain & $\begin{array}{c}1000 \\
\text { grains }\end{array}$ \\
\hline $\begin{array}{l}\text { Pamyat, } \\
\text { st }\end{array}$ & 10,8 & 20,5 & 1,1 & 47,3 & 2,5 & 1,9 & 40,2 \\
\hline Course & 10,5 & 22,6 & 2,0 & 30,2 & 1,1 & 0,95 & 34,5 \\
\hline Kalym & 7,9 & 18,8 & 3,2 & 31,1 & 1,4 & 1,0 & 45,0 \\
\hline Adele & 7,0 & 17,4 & 1,3 & 42,7 & 1,7 & 1,6 & 37,5 \\
\hline
\end{tabular}

The length is the one of the most important factors determining the productivity of the spike. Among the studied varieties, according to the results of our experiments, the best indicators were at Pamyat variety. The average length of the its spike was $10,8 \mathrm{~cm}$. The Course variety conceded to the standard by only $0,3 \mathrm{~cm}$. Adele and Kalym had very nearly results of 7,0 and 7,9 cm, respectively. Their length reduction was 3,8-2,9 $\mathrm{cm}$ in relation to the standard.

Analysis of the number of spikelets in the spike revealed that the Course variety had the best results - 22,6 spikelets, which is higher than the Pamyat variety by 2,1 pcs. The varieties Adele and Kalym formed 17,4-18,8 spikelets, and were inferior to the standard for this indicator.

Of the four varieties studied, the largest number of grains in the ear was found in the standard variety-47.3 pcs., the remaining varieties were inferior to the standard. The number of grains in the ear of the Kalym variety was 31.1 pcs., Adel and Course in experimental conditions had 30.2 and 42.7 grains.. For the Pamyat variety, the lowest value of the number of undeveloped spikelets was 1.1 pcs., the other varieties had from 1.3 to 3.2 pcs. of undeveloped spikelets in the ear.

When we determine the weight of 1000 grains, it was revealed that the Kalym variety had the most heaviest grain, its indicators were 45,0 grams, exceeding the standard by 4,8 grams.

In general, the comparison of the ear weight revealed the advantage of the standard, the Pamyat variety formed an ear of up to 2.5 grams, the studied varieties gave it $0.8-1.7$ grams.

The yield of the variety is the resulting indicator that reflects its adaptability to the specific conditions of cultivation. In our experiments, the highest values were obtained for the Kalym variety, which on average formed 62,2 cwt/ha, which was higher than that of the Pamyat variety by 6,7 cwt/ha. The Adele and Course varieties exceeded the standard by 1,7-2,7 cwt/ha (Table 3).

Table 3. Yield of winter soft wheat varieties (KubSAU experimental station, 2017-2018)

\begin{tabular}{|l|c|c|c|}
\hline \multirow{2}{*}{ Variety } & \multirow{2}{*}{ Yield, cwt/ha } & \multicolumn{2}{|c|}{ Deviation from the standard } \\
\cline { 3 - 4 } & & cwt/ha & $\%$ \\
\hline Pamyat, st & 55,5 & - & - \\
\hline Course & 57,2 & 1,7 & 3 \\
\hline Kalym & 62,2 & 6,7 & 42 \\
\hline Adele & 58,2 & 2,7 & 4,9 \\
\hline SSD 05 & 2,64 & & \\
\hline
\end{tabular}

Thus, a comparison of the data on the productivity of the ear shows that the Pamyat variety most fully implements the inherent genetic potential, forms the heaviest ear, but is inferior to the experimental varieties in terms of yield, which is explained by a lower level of productive bushiness of this variety. The studied varieties, being inferior to grain 
formation of the ear, formed high yield indicators, due to a more powerful density of standing plants.

\section{References}

1. V. A. Akhundova, Z. A. Morozova, V. V. Murashev, E. A. Sedova, E. V. Turkova Morphogenesis and plant productivity. Moscow University., Moscow., 160 p. (1994)

2. V. V. Ivashchenko Selection and genetic assessment of quantitative traits of winter soft wheat varieties on adaptivity in connection with selection for homeostaticity Dissertation for the degree of Candidate of Biological Sciences., Krasnodar, 190 p. (2002)

3. V. V. Kazakova, E. M. Kabanova, A. S. Yakusheva Characteristics of hybrid families of winter soft wheat Garant and Pervitsa (F 3-4) and parent forms on the elements of spike productivity. Proceedings of the Kuban State Agrarian University. 45. pp. 108-112. (2013)

4. V. V. Kazakova, E. M. Kabanova, Yu. V. Zhuk Evaluation of hybrid families F 3 of winter soft wheat in comparison with parent forms by quantitative characteristics of ear productivity. Proceedings of the Kuban State Agrarian University. 41. pp. 73-80. (2013)

5. S. S. Koshkin, L. V. Tsatsenko Realization of potential productivity of old-fashioned varieties of winter soft wheat. Polythematic network electronic scientific journal of the Kuban State Agrarian University. 115. pp. 829-848. (2016)

6. F. M. Kuperman Plant morphophysiology: Morphophysiol. analysis of the stages of organogenesis of various lifetimes. the forms are covered by the family. plants : [Textbook for biol. specialties of universities] 3rd ed., add. - Moscow: Higher School 288 p. (1977). 